\title{
Useful work for idle hands or a brightening and elevating influence? The introduction of the Brabazon Employment Scheme to Glasgow's public institutions in the late $19^{\text {th }}$ century.
}

\section{Emma Halliday}

Division of Health Research, Lancaster University, Lancaster, UK

Correspondence to

Division of Health Research, Faculty of Health and Medicine, Lancaster University, Lancaster LA1 4QT, UK. e.halliday@lancaster.ac.uk

orcid.org/0000-0002-2216-9259

\section{Biographical note}

Emma Halliday completed her $\mathrm{PhD}$ 'Themes in Scottish asylum culture: the hospitalisation of the Scottish asylum 1880-1914' in 2003. Since then she has worked in research roles in the higher education, charitable and public sectors with a focus on public health and inequalities. She has been employed as a researcher at Lancaster University since 2010. She remains interested in how historical perspectives can be better utilised to offer insights into contemporary understanding of social issues.

\section{Word count: 5911 (including footnotes)}




\title{
Useful work for idle hands or a brightening and elevating influence? The introduction of the Brabazon Employment Scheme to Glasgow's public institutions in the late $19^{\text {th }}$ century.
}

\author{
Women's ability to effect changes in welfare policy during the later workings of \\ the new Poor Law has been presented as a 'marginal influence' within past \\ historiography. This perspective is contested in recent empirical work, which \\ argues for a more positive view of female agency. The Brabazon Employment \\ Scheme was a charitable initiative, which occupied the poor unable to take part in \\ the routine work of public institutions. Findings from its operation in Glasgow \\ demonstrate how women drew upon philanthropic experience as well as elected \\ positions in the management of institutions to secure the scheme's introduction in \\ these settings. While the initiative originated in the English workhouses, local \\ women extended the Brabazon activities to address gaps in welfare provision for \\ asylum patients. In doing so, the article shows how organised charity continued \\ to function as an avenue of support for the poor alongside municipal relief into \\ the early $20^{\text {th }}$ century.
}

Keywords:

philanthropy; women; asylum; poor law; Glasgow; Scotland 


\section{Introduction}

The growing 'professionalisation of philanthropy' was, as Kathyrn Gleadle has argued, an important factor influencing how women participated in community affairs by the late 19 th century. ${ }^{1}$ Charitable work such as campaigning, fundraising and visiting offered a route for women to become actively involved in workhouses and other public institutions. ${ }^{2}$ Increasing numbers of women were also elected to roles in public life, after the 1894 Local Government Act (LGA) enabled women to stand as district and parish councillors and abolished the property qualification needed for election as a Poor Law Guardian. ${ }^{3}$ Recent scholarship has sought to more fully understand the achievements of 'ordinary' women involved in local welfare activities during the later decades of the new Poor Law. ${ }^{4}$ Responding to past historiography that has often documented women's involvement in this sphere as a 'marginal influence', historians such as Steven King have undertaken detailed empirical studies to provide a more balanced assessment of women's efforts to effect change locally. ${ }^{5}$

The article aims to contribute to this body of more contextualised research by examining a charitable initiative organised by women. The Brabazon Employment

${ }^{1}$ K. Gleadle, British Women in the Nineteenth Century, (Basingstoke: Palgrave Macmillan, 2001), p. 67-68.

${ }^{2}$ F.K. Prochaska, Women and Philanthropy in Nineteenth-century England, (Oxford: Clarendon Press, 1980), p. 174.

${ }^{3}$ P. Hollis, Ladies Elect: Women in English Local Government, 1865-1914, (Oxford University Press, 1989), p. 208.

${ }^{4}$ S. King, “We Might be Trusted”: Female Poor Law Guardians and the development of the New Poor Law: The case of Bolton, England, 1880-1906', International Review of Social History, 49 (2004), p. 31-32.

${ }^{5}$ S. King, Women, Welfare and Local Politics, 1880-1920, (Eastbourne: Sussex Academic Press, paperback edition, 2010), p.116. 
Scheme [hereafter BES] was aimed at the poor housed in $19^{\text {th }}$ century institutions such as workhouses and asylums. By drawing on a range of primary sources, the findings illustrate how women utilised philanthropic experience alongside elected roles in municipal affairs to secure the scheme's introduction. Rather than only encountering hostility, I will argue that women worked cooperatively with male officials to implement the BES and that their involvement was largely met with a positive reception from Poor Law officials and asylum doctors.

The research also aims to contribute to the historiography of women's participation in Scotland. While contextualised studies are accumulating, their coverage has mainly focused on the English situation. ${ }^{6}$ Megan Smitley argues for research with a 'stronger appreciation of diversity' given differences in Scotland's legal and administration arrangements. ${ }^{7}$ Smitley's work seeks to address this gap in scholarship but focuses on temperance and suffrage movements rather than welfare. While Olive Checkland's monograph is a detailed account of philanthropy in Scottish welfare and health policy, it was published over 30 years ago and does not specifically consider women's contributions. ${ }^{8}$

${ }^{6}$ See for example, M. Martin, 'Single Women and Philanthropy: a case study of women's associational life in Bristol, 1880-1914', Women's History Review, 17 (2008), p. 395-417; N. Quinn, 'Men of Yesterday: Lancaster Poor Law Union, 1870-1911', Family \& Community History, 18 (2015), p. 3-23.

${ }^{7}$ M. Smitley, The Feminine Public Sphere. Middle-class women and civic life in Scotland, 1870-1914, (Manchester University Press, 2009), p. 12.

${ }^{8}$ O. Checkland, Philanthropy in Victorian Scotland: Social Welfare and the Voluntary Principle, (Edinburgh: John Donald, 1980). 


\section{Public institutions and the Poor Law in Scotland}

Scotland's Poor Law Amendment Act was introduced in 1845. A key distinction from the 1834 (England and Wales) Act was that anyone deemed fit to work (able bodied) was not entitled to indoor or outdoor parish relief. ${ }^{9}$ This ruling had implications for the naming of the Scottish equivalent of 'workhouses'. Such institutions, as Andreas Gestrich and John Stewart explain, took the form 'not as in England, of a workhouse, but rather of the poorhouse for the sick, the infirm and the elderly who were not able to work' ${ }^{10}$ By 1894, the number of poorhouses in Scotland increased threefold to 66 from 21 in $1850 .{ }^{11}$ Much of the general historiography of Scotland's Poor Law was produced in the 1970s and 1980s, ${ }^{12}$ although a few more recent localised studies are available. ${ }^{13}$ These have suggested that the Scottish principle (i.e. who was deemed 'disabled' or sick') was subject to some interpretation at the local level, with eligibility for relief applied more or less stringently depending on circumstance. ${ }^{14}$

${ }^{9}$ D. Englander, Poverty and Poor Law Reform in $19^{\text {th }}$ Century Britain, 1834-1914 from Chadwick to Booth, (Harlow: Longman, 1998), p. 47.

${ }^{10}$ A. Gestrich and J. Stewart, 'Unemployment and Poor Relief in the West of Scotland', in S. King and J. Stewart (ed.), Welfare Peripheries. The Development of Welfare States in Nineteenth and Twentieth Century Europe, (Bern: Peter Lang AG, 2007), p.128.

${ }^{11}$ Englander, Poverty and Poor Law Reform, p. 53.

${ }^{12}$ See Englander, Poverty and Poor Law Reform, p. 47-55 for an overview of Poor Law arrangements in Scotland.

${ }^{13}$ See for example, A. Blaikie, 'Accounting for Poverty: Conflicting Constructs of Family Survival in Scotland, 1855-1925,' Journal of Historical Sociology, 18 (2005), p. 202-226;

Gestrich and Stewart, 'Unemployment and Poor Relief', p. 125-148.

${ }^{14}$ Blaikie, 'Accounting for Poverty', p. 203. 
Statutory provision for the mentally ill poor in Scotland was formalised in the 1857 Lunacy (Scotland) Act. This Act resulted in the construction of 20 district and parochial asylums by the early $20^{\text {th }}$ century, which supplemented existing accommodation in Scotland's 7 Royal Asylums (for private and pauper patients), private 'madhouses' and poorhouse wards licensed for the mentally ill. ${ }^{15}$ As Cathy Smith highlights, the rise in asylum admissions during the late $19^{\text {th }}$ century suggests that there was little 'shortage of demand' once such institutions were built. ${ }^{16}$

\section{Origins of the Brabazon Employment Scheme}

The BES was founded by the couple Reginald and Mary Jane Brabazon. Reginald Brabazon, 12 $2^{\text {th }}$ Earl of Meath (1841-1929) was born into a family of Anglo-Irish landowners and married Lady Mary Jane Maitland (1847-1918) in 1868. Historians broadly align Reginald Brabazon's philanthropic and public causes to the physical and moral improvement of the poor in congested urban areas and the strengthening of Britain's imperial identity. ${ }^{17} \mathrm{He}$ is associated with the open spaces movement, ${ }^{18}$

${ }^{15}$ P. Bartlet and D. Wright, Outside the Walls of the Asylum: The History of Care in the Community 1750-2000: On Care in the Community in Modern Britain and Ireland, Studies in Psychical Research, (London: The Athlone Press, 1999), p. 87.

${ }^{16} \mathrm{C}$. Smith, 'Family, Community and the Victorian asylum: a case study of the Northampton General Lunatic Asylum and its Pauper Lunatics', Family \& Community History, 9 (2013), p. 110.

${ }^{17}$ F. Aalen, 'Lord Meath, city improvement and social imperialism', Planning Perspective, 4 (1989), p.131-132.

${ }^{18} \mathrm{C}$. Hickman, 'To brighten the aspect of our streets and increase the health and enjoyment of our city: The National Health Society and urban green space in late-nineteenth century London', Landscape and Urban Planning, 118 (2013), p. 115. 
supporting youth programmes and founding the Empire Day Movement. ${ }^{19}$ Less is written about Mary Jane Brabazon in the secondary literature but diaries documenting her public life were published posthumously by her husband. ${ }^{20}$ She established the Ministering Children's League and supported the Workhouse Concert Society before instigating the BES in the 1880 s. $^{21}$ The couple also had some involvement in mental health activities. Reginald Brabazon became president of the Mental After Care Association in 1885 and the couple donated funds to open a 'Home of Comfort for Epileptic Women and Girls' in 1892.

The BES was first proposed at a meeting of the Metropolitan Poor Law Guardians' Association (MPLGA) in 1882. Here, the idea for the scheme was put forward on Mary Jane Brabazon's behalf by her husband. ${ }^{22}$ The BES aimed to occupy inmates unable to take part in the workhouse regime due to old age, disability or ill health and intentionally excluded those able to work. ${ }^{23}$ In her MPLGA statement, Mary Jane Brabazon called for:

... permission of the Board of Guardians to allow me to give materials for providing some sort of light fancy work for patients in infirmary wards who are at present wholly, or at most, only partially employed. In no case would I wish to interfere with the labour of those who are already better engaged in doing the

${ }^{19}$ B. Beaven and J. Griffiths, 'Creating the exemplary citizen: the changing notion of citizenship in Britain 1870-1939', Contemporary British History, 22 (2008), p. 208-209.

${ }^{20}$ R. Brabazon (ed.), The Diaries of Mary, Countess of Meath. Volume 1 \& 2, (London: Hutchinson \& Co., 1928).

${ }^{21}$ Prochaska, Women and Philanthropy, p. 180.

${ }^{22}$ Brabazon, Diaries of Mary, Countess of Meath. Volume 1, p. 46.

${ }^{23}$ M.A. Crowther, The Workhouse System 1834-1929. The History of an English Social Institution, (London: Methuen \& Co, 1981), p. 70-71. 
needful work of the Institution that supports them, for I fully appreciate the fact that a pauper's labour should go towards his maintenance. ${ }^{24}$

Following MPLGA's endorsement, the Brabazons offered a grant of $£ 50$ each to up to 8 workhouses willing to trial the BES. ${ }^{25}$ In 1883, the Union Poorhouse in Tonbridge, Kent was the first to implement the scheme. Female visitors to the workhouse, usually attending on a weekly basis, trained inmates in handicraft skills such as woodwork, embroidery and basket making. The 'goods' were subsequently sold at a fundraising event organised by the women. Such sales raised funds to buy new handicraft materials and provide occasional entertainments or small luxuries (e.g. newspapers or magazines) to act as an 'incentive to work' ${ }^{26}$ A national headquarters of the Brabazon Society was established in London although it is unclear if its records have survived.

Mary Jane Brabazon's diaries evidence a personal interest in the scheme's success particularly in its earlier years. Entries document her visits to observe the scheme in workhouses often accompanied by other female acquaintances. Initially the BES appears to not have gained the uptake that she hoped for. Her diary entry for December $8^{\text {th }} 1885$, while praising of the quality of work produced by inmates, commented that the scheme 'does not seem to extend itself very much, as I notice the same workers from year to year, and not so many new ones as I should like to see'. ${ }^{27}$ By 1901, nevertheless, the scheme was operating in over 200 workhouses and other public institutions with the model extended to soldiers returned from the Boer war. ${ }^{28}$

\footnotetext{
${ }^{24}$ Brabazon, Diaries of Mary, Countess of Meath. Volume 1, p. 49.

${ }^{25}$ Ibidem, p. 50.

${ }^{26}$ Crowther, The Workhouse System 1834-1929, p. 70.

${ }^{27}$ Brabazon, Diaries of Mary, Countess of Meath. Volume 1, p. 81.

${ }^{28}$ Brabazon, Diaries of Mary, Countess of Meath. Volume 2, p. 25.
} 
While Anne Crowther refers generally to the existence of BES in her account of the English workhouse system ${ }^{29}$, no case study exists of its local operation.

\section{Sources}

Archive searches identified the survival of catalogued BES or Brabazon Society records to be limited. ${ }^{30}$ Primary source materials included parish record collections such as minutes of Poor Law meetings as well as diaries and biographies of women involved in BES. Asylum records included annual reports prepared by the Medical Superintendent (head doctor) and the Journal of Mental Science [hereafter JMS]. The JMS was the official journal of the Medico Psychological Association [hereafter MPA] providing the opinions of MPA members, as well as excepts from asylum annual reports in different parts of the UK. Patient case notes were examined for reference to the scheme, although mention of the BES in this source tended to be infrequent.

\section{Introduction of BES to Glasgow's poorhouses}

In Glasgow, the 1845 Act established 4 parochial boards to administer the Poor Law. With administration distributed between the parishes of Barony, City, Govan and Gorbals, indoor relief was available in 3 poorhouses across the city. Glasgow's population grew significantly as a result of urbanisation during the $19^{\text {th }}$ century. In Barony parish alone, the local population increased from 106,075 in 1841 to 289,457 by

\footnotetext{
${ }^{29}$ Crowther, The Workhouse System 1834-1929, p. 70-71 \& 200-201.

${ }^{30}$ The National Archive's Discovery catalogue (http://discovery.nationalarchives.gov.uk) catalogues local records for Brabazon Society branches in Kensington, Metropolitan Borough, Stroud, Burton on Trent, Doncaster and Newton Abbot.
} 
1875. ${ }^{31}$ David Englander has argued in general terms that numbers receiving indoor relief across Scotland's poorhouses never exceeded the accommodation available. ${ }^{32}$ This may mask some variation in demand in different regions. In Glasgow, Ronald Johnston suggests cyclical unemployment combined with inward migration of unskilled workers resulted in a substantial rise in applicants seeking shelter in the city's poorhouses as well as increased levels of homelessness and crime. ${ }^{33}$

In October 1895, a letter submitted by a Miss Allan of Carstairs to Barnhill House Committee proposed the introduction of the BES to the poorhouse. ${ }^{34}$ Following consideration by the House Committee at the same meeting, a 6 month trial period under Allan's supervision was sanctioned. Eliza Jane Aikman, a House Committee member and newly elected member of Barony Parish Council, was allocated the task of working with Barnhill's governor Alexander Henderson to monitor the pilot.

Six months on, Aikman and Henderson reported that the scheme was tried positively with 19 females, 9 males and 3 children in the infirm and hospital wards.

There is no doubt but the scheme has been the means of providing a variety of employment for the inmates engaged in it, creating new interest and giving them relief from the routine work and life of the house and this has been accomplished

${ }^{31}$ T.C. Smout (ed.), The Search for Wealth and Stability: Essays in Economic and Social History, (London: Macmillan, 1979), p. 248.

${ }^{32}$ Englander, Poverty and Poor Law Reform, p. 53.

${ }^{33}$ R. Johnston, 'Charity That Heals: The Scottish Labour Colony Association and Attitudes to the Able-Bodied Unemployed in Glasgow, 1890-1914', The Scottish Historical Review, 77 (1998), p. 79-80.

${ }^{34}$ Glasgow City Archives (GCA), D-Hew 2.2.19, Minutes of the Barony Parish Council and Committee Vol. 20, 11/4/1895 - 30/11/1896, p. 264. 
without in anyway interfering with the management or discipline of the institution..$^{35}$

Following the scheme's operation for another year, Allan - who now had charge of a newly established Glasgow branch of the Brabazon Society - submitted a request to the House Committee for a sale of Brabazon 'goods'. ${ }^{36}$ This took place in November 1896 with profits from the sale used to put on an evening's entertainment for all poorhouse inmates, to which the House Committee was 'cordially invited' ${ }^{37}$ By 1899 , the scheme was extended to the City poorhouse, with an application made to the national headquarters 'for a grant from the Society's funds to launch the scheme'. ${ }^{38}$

The BES in Glasgow thus far shares similarities to its operation in the English workhouse. Crowther argues that the scheme was popular with workhouse governors because it offered a solution in how to occupy those unable to work, but was also accepted by the poor because it was not run by the workhouse staff. ${ }^{39}$ In Glasgow, women such as Aikman cooperated with Poor Law officials to trial the scheme and offer reassurance that it would not interfere with the institution's discipline. The sales of goods made by the participants also enabled the scheme to become self-funding and thus not reliant on municipal funds.

Local women took on different roles in organising the BES. Although difficult to locate biographical information about Allan, she was reportedly unmarried but

\footnotetext{
${ }^{35}$ Ibid., p. 316.

${ }^{36}$ Ibid., p. 351.

${ }^{37}$ Ibid., p. 365.

${ }^{38}$ Greater Glasgow Health Board Archives (GGHBA), HB30/1/1, Minutes of the Glasgow District Lunacy Board 1898-1899.

${ }^{39}$ Crowther, The Workhouse System 1834-1929, p. 200-201.
} 
evidently financially secure, covering the initial $£ 50$ outlay for materials at Barnhill. ${ }^{40}$ Support from influential philanthropic networks was obtained when Lady Bell - wife of Sir James Bell, Lord Provost of Glasgow - was appointed as the Glasgow branch president. Aikman, the daughter of a Glaswegian Presbyterian minister, was instated as the Honorary Secretary. Aikman was involved in local politics, serving as a councillor on the Barony Parish Council between 1895 and 1902 and on Glasgow’s Parish Council until 1907. ${ }^{41}$ Both Aikman and V.C. (first name unknown) Bannatye, another woman connected with the Glasgow branch of the Brabazon Society, were invited to give evidence about their experience of welfare work to the 1904 committee reviewing the Poor Law system of medical relief in Scotland. ${ }^{42}$ Primary records do not indicate how Bannatye was involved with the BES, however, her evidence to this committee show her to be active in public life as a member of the Glasgow School Board and as a former district secretary for the Charity Organisation Society. ${ }^{43}$

\section{Spread of BES to Glasgow's asylums}

In 1898, the BES was introduced to Woodilee District Asylum (opened in 1875) and in 1899 to Gartloch Asylum and Hospital (opened in 1896). These asylums provided

${ }^{40}$ H.C. Marr, 'The Brabazon Scheme in an Asylum; History of its Introduction, and Record of a Year's Working', Journal of Mental Sciences, 45 (1899), p. 534.

${ }^{41}$ H. Alexander, Eliza Jane Aikman: A Memoir, (Glasgow: Anderston Church, 1930), p. 8-10.

${ }^{42}$ Aikman's written statement and Bannatye's oral statement are contained in the body of evidence of witnesses from Scotland. See Royal Commission, Report on the Poor Laws and Relief of Distress: Appendix Volume VI. Minutes of evidence (95th to 110th days and 139th and 149th days) with Appendix, (London: HMSO, 1910). Available as electronic book from Wellcome Library collection online: http://wellcomelibrary.org [accessed 18 June 2016].

${ }^{43}$ Ibid., p. 307. 
accommodation for the mentally ill poor living in the Barony and City parishes. While local women instigated the scheme in the poorhouse, minutes of a Woodilee Asylum Committee meeting held $19^{\text {th }}$ October 1897 , suggest that the impetus to trial BES at Woodliee came from its then medical officer Hamilton Clellend Marr. ${ }^{44}$ Glasgow's Lunacy Board sanctioned $£ 70$ to be used for initial startup costs, ${ }^{45}$ with this initial sum 'paid off' within a year, following a sale of Brabazon goods, opened by the Duchess of Montrose. $^{46}$ In an outline of the scheme's introduction, Marr reported that Aikman (also a member of the Woodilee Asylum Committee) had helped facilitate the scheme's introduction by acting as a 'medium between the officials of the asylum and the [Brabazon] committee of ladies' ${ }^{47}$

Marr was publically supportive of BES, writing a $J M S$ article about the scheme in 1899 aimed at his professional peers. ${ }^{48}$ His support in part contradicts the movement to hospitalise Scotland's asylums during the late 19th century and promote these as medical institutions. ${ }^{49}$ Marr would become a notable Scottish psychiatrist, as a Medical Superintendent of Woodilee and Commissioner of Lunacy on the General Board of

${ }^{44}$ GCA, D-Hew 2.2.20, Minutes of the Barony Parish Council and Committee Vol. 21, 2/12/96 $-8 / 9 / 1897$, p. 355.

${ }^{45}$ Ibid., p. 361.

${ }^{46}$ Marr, 'The Brabazon Scheme in an Asylum', p. 536.

${ }^{47}$ Ibid., p. 535.

${ }^{48}$ Ibid., p. 572-573.

${ }^{49}$ The term 'hospitalisation' was adopted by late 19th century psychiatrists to describe an approach to asylum construction and treatment in Scotland that aimed to integrate general hospital features into asylums. For further details: E. Halliday, Themes in Scottish Asylum Culture: the Hospitalisation of the Scottish Asylum 1880-1914. (Unpublished thesis, University of Stirling, 2003), Available from STORRE [online]. Available from: http://hdl.handle.net/1893/3265 [Accessed 18 June 2016]. 
Lunacy. ${ }^{50}$ Checkland suggests, however, that many public asylums in Scotland at the time were affected by rising admissions and low recovery rates. ${ }^{51}$ Since opening in 1875 , Woodilee's admissions increased from an average of 170 patients per year in the late 1880 s to nearly double that figure by 1900 , with its annual report observing the 'increasing readiness with which the aged, feeble minded and naturally defective in intellect are now committed to asylums', 52

\section{More varied occupation or therapeutic benefit?}

As Roy Porter argues, while occupation underpinned the moral treatment of mental illness in the early $19^{\text {th }}$ century, a more personalised approach to care declined with the growth of publicly funded asylums. ${ }^{53}$ Since opening, occupation in the asylum farms and gardens formed part of the daily routine for male patients in Gartloch and Woodilee with women engaged in domestic chores such as knitting or sewing. ${ }^{54}$ In Marr 's opinion, the BES could offer alternative occupation for 'paralytic' and 'bedridden' patients unable to participate in manual work and female patients where household activities were in his view 'manifestly unsuited to relieve their minds of morbid thought' ${ }^{55}$ After a year's operation, visiting Lunacy Commissioners commended

${ }^{50}$ G. Davies, The "Cruel Madness of Love": Sex, Syphilis and Psychiatry in Scotland, 18801930, (Amsterdam: Rodopi, 2008), p. 69.

${ }^{51}$ Checkland, Philanthropy in Victorian Scotland, p. 176.

${ }^{52}$ GGHBA, HB30/2/10, 22 ${ }^{\text {nd }}$ Annual Report of Woodilee District Asylum, 1897.

${ }^{53}$ R. Porter, Madness: A Brief History, (Oxford: University Press, 2002), p. 120.

${ }^{54}$ GGHBA, HB30/2/1, Woodilee Patient Books containing Twice Yearly Reports by Her Majesties Commissioner in Lunacy 1875-1895.

${ }^{55}$ Marr, 'The Brabazon Scheme in an Asylum', p. 534-5. 
Woodilee's 'efforts to secure more varied employment for Asylum patients' ${ }^{56}$

To what extent did asylum doctors view the scheme to have therapeutic benefit? Brabazon classes took place on a weekly basis for relatively small numbers, with an average of 50 patients taking part each year. It is unclear whether classes attracted new admissions or remained limited to the same cohort each week. Marr observed that he could 'call to mind one or two cases whose recoveries may be traced to the good offices of the Brabazon society'. ${ }^{57}$ Gartloch's Medical Superintendent Landel Oswald noted 'the interest taken by the visiting ladies in the workers has been productive of mental improvement in not a few' ${ }^{58}$ F.M. was a male patient admitted to Woodilee in 1897. By May 1898 he had 'started working with the Brabazon Class and is taking a great interest in the work' ${ }^{59}$ By the following November, the patient was still involved, having 'done very good work at the Brabazon Class. Being employed seems to have done him a lot of good'. In spring 1899, the patient's casenote record 'is still working hard at his Brabazon work. He is now working on a large rug, which is to be sent to London. Fits are not nearly so frequent' ${ }^{60}$ Another patient - W.S. - from Gartloch was similarly reported to have 'been much interested in box painting at the Brabazon when he is well'. 61

Brabazon volunteers arranged occasional events and entertainments for all patients such as musical productions, summer picnics and Christmas shows. Individuals

\footnotetext{
56 Anonymous, 'Psychological retrospect - Some Scottish District Asylums', JMS, 45 (1899), p. 399.

${ }^{57}$ GGHBA, HB30/2/12a , 27 $7^{\text {th }}$ An. Rep. of Woodilee, 1901-1902.

${ }^{58}$ GGHBA, HB1/6/3, $3^{\text {rd }}$ An. Rep. of Gartloch Asylum and Hospital, 1900.

${ }^{59}$ GGHBA, HB30/4/4, Woodilee Casebook No. 4 Male, 1896-1899.

60 Ibid.

${ }^{61}$ GGHBA, HB1/14/4, Gartloch Casebook Vol. 4 Male, 1899.
} 
like Aikman, involved in the scheme for over two decades at Woodilee, became a familiar figure reportedly going 'quietly and unconstructively in amongst them [the patients] with her large parcels of newspapers and magazines under her arm' ${ }^{62}$ The women, accompanied by asylum staff, also funded occasional excursions for patients. The following extract (year and asylum unstated) describes an outing organised for patients.
Aikman and the lady who was paying the expense, with thirty patients, matron and nurses, sailed from the Broomielaw for Rothesay where a happy time was spent on the beach. ${ }^{63}$

Another Brabazon volunteer named Mrs Inglis was similarly given a particular mention in Gartloch's annual report for organising a seaside outing for patients in $1904 .{ }^{64}$

\section{An intermediary between asylum and community}

While $18^{\text {th }}$ century philanthropists had invested in the construction of Scotland's Royal asylums, ${ }^{65} 19^{\text {th }}$ century Scottish psychiatrists drew attention to the apparent lack of charitable support for the mentally ill poor. In England and Wales, a Mental After Care Association [henceforth MACA] had been formed in 1877 by Reverend Hawkins, chaplain of Colney Hatch Asylum. ${ }^{66}$ Its aim was to bridge the gap for patients between asylum life and society through monetary support and convalescent homes for patients

\footnotetext{
${ }^{62}$ Alexander, Eliza Jane Aikman, p. 13-14.

${ }^{63}$ Ibid., p. 14.

${ }^{64}$ GGHBA, HB1/6/7, $7^{\text {th }}$ An. Rep. of Gartloch, 1905.

${ }^{65}$ For an account of philanthropy and Scotland's Royal Asylums, see Checkland, Philanthropy in Victorian Scotland, p. 168-69.

${ }^{66} \mathrm{~J}$. Smith, 'Forging the 'missing link': the significance of the Mental After Care Association archive', History of Psychiatry, 8 (1997), p. 407-408.
} 
close to discharge. ${ }^{67}$ Asylum doctors like Oswald commented upon the absence of a similar scheme in Scotland.

Is it too much to hope that this [Brabazon] interest will not cease when the patients leave the asylum? Many go out to find their situations filled up, their means exhausted, and it may be their homes broken up. Is it surprising that some of these relapse? There are many Associations and charities appealing to the benevolent of Glasgow, but none dealing with the insane poor, who are left out of all schemes of charitable work. ${ }^{68}$

Why the 'insane poor' were seemingly 'left out' of charitable work is seen in efforts to introduce the Brabazon scheme in Woodilee. Aikman's memoirs record not 'inconsiderable' challenges in getting the classes underway as a result of 'prejudice in the mind of the general public as well as the fear that it might upset the normal working of the Institution'. ${ }^{69}$ In response to Marr's 1899 article, a JMS editorial observed

${ }^{67}$ Despite the Brabazon couple's involvement in both BES and MACA, there is no evidence that the couple influenced the introduction of BES into Glasgow's asylums. Hawkins suggests that the MACA benefited from the 'prestige' of association with the Brabazon family connection, but that Brabazon was 'seldom able to attend meetings'. H. Rev. Hawkin, 'Reminiscences of “After-Care” 1879-1898', JMS, 44 (1898), p. 301.

${ }^{68}$ GGHBA, HB1/6/2, $2^{\text {nd }}$ An. Rep. of Gartloch, 1899.

${ }^{69}$ Alexander, Eliza Jane Aikman, p. 13. 
...hitherto the scheme has been in working in workhouses and infirmaries only, but the Brabazon ladies are evidently prepared to carry their enterprise into the more difficult sphere of asylums. ${ }^{70}$

Giving oral evidence to the Royal Commission on the Poor Laws, Bannatyne was questioned by the chair whether 'it is more difficult to get the ladies to work with the lunatics than the others', to which Bannatyne responded that this had not been the case because 'they [the women] know that the nurses are always present'. ${ }^{71}$

Once inside the asylum, individuals like Aikman extended their role beyond BES activities. Her Memoir reports that she acted as a bridge between families and patients in the Barony parish 'inducing the relatives to resume their interest' in family members committed to the asylum. ${ }^{72}$ In 1901 , a bequest by local women (who wished to remain anonymous but likely connected to BES) enabled Marr to set up a small aftercare fund for Woodilee patients. ${ }^{73}$ This aftercare provision was more formally established in 1905 with a constituted Brabazon After Care Association (BACA). The Association's primary role was to 'facilitate the return of indoor poor chargeable to the Parish of Glasgow into the social life of the community' and was for patients discharged from Woodilee and Gartloch as well as from the parish hospitals. ${ }^{74}$

The BACA offered a grant of money or clothing or support to find employment, or a period in a convalescent home on discharge. The female patient I.J. who was admitted to Gartloch in August 1907 was reported to be in a state of convalescence by

\footnotetext{
${ }^{70}$ Anonymous, 'The Brabazon Scheme in Asylums', JMS, 45 (1899), p. 572.

${ }^{71}$ Royal Commission, Report on the Poor Laws and Relief of Distress, p. 318.

${ }^{72}$ Alexander, Eliza Jane Aikman, p. 14.

${ }^{73}$ GGHBA, HB30/2/12a, 27 $7^{\text {th }}$ An. Rep. of Woodilee, 1901-1902.

${ }^{74}$ GGHBA, HB30/2/17, 35 ${ }^{\text {th }}$ An. Rep. of Woodilee, 1909-1910.
} 
December 1907, with her name put before the BACA. ${ }^{75}$ By January 1908, this resulted in the patient having been 'got place with Samaritans in laundry and discharged'. ${ }^{76}$ Administration of BACA relief was put in the 'hands of a committee' made up of women from the Glasgow branch of the Brabazon Society ${ }^{77}$. Who was deemed eligible for this relief remained under the control of Glasgow's Inspector of the Poor. Following notification by the Medical Superintendent of patients close to discharge, it was the Inspector who approved whether 'he considers it a suitable case for this Association'. ${ }^{78}$

\section{Legacy of the BES}

Although the BES spread to only a small number of Scottish poorhouses, the scheme still attracted interest from national Poor Law administrators by the early $20^{\text {th }}$ century. In the Departmental Committee report on Poor Law Medical Relief for Scotland (1904), the Brabazon Society was commended for the 'efforts to now being made to provide some light employment for the sick and infirm inmates of our poorhouses' ${ }^{79}$ Excerpts from $J M S$ asylum updates show that the Glasgow experience led to the scheme's introduction in other asylums. In 1903, the Derby Asylum's Medical Superintendent reported the "'Brabazon morning"' to have become 'a regular institution, and is looked

${ }^{75}$ GGHBA, HB1/13/15, Gartloch Case Book Vol. 15 Female, 1907.

${ }^{76}$ Ibid.

${ }^{77}$ GGHBA, HB30/2/17, 35 ${ }^{\text {th }}$ An. Rep. of Woodilee,1909-1910.

${ }^{78}$ Ibid.

${ }^{79}$ Local Government Board for Scotland, Report of the Departmental Committee appointed by the Local Government Board for Scotland to inquire into the system of poor law medical relief and into the rules and regulations for the management of poorhouses, (Edinburgh: HMSO, 1904). Available as electronic book from Wellcome Library collection online: http://wellcomelibrary.org [accessed 18 June 2016], p. 65. 
forward to by the patients as the event of the week' ${ }^{80}$

Marr would later claim that BES represented a forerunner of $20^{\text {th }}$ century occupational therapy. Now a Commissioner for Lunacy, Marr was quoted in Aikman's Memoir as suggesting 'it was the result of the inspection of the Brabazon work in this country that the idea of occupational therapy arose in America'. ${ }^{81}$ Despite no proven evidence for this, ${ }^{82}$ David Henderson, the then medical superintendent of Glasgow Royal Mental Hospital (formally Gartnavel Royal Asylum) argued that BES represented an attempt to return to a more personalised use of occupation amid the 'utilitarian and economic point of view', ... [where] 'the curative aspect, if considered at all, has largely been lost sight of ${ }^{83}$

\section{Conclusion}

By the early $20^{\text {th }}$ century, local women replicated the English workhouse model of BES in Glasgow's poorhouses and extended the Brabazon Society's activities to the mentally ill. Individual women like Aikman deployed influence and persuasion within elected positions as well as gaining support and trust of the institutions' management and staff in negotiating its introduction. Her ability to effect change in this way reflects other contextualised research in Bolton and Bristol that has found local women combining strategic influence and practical efforts to facilitate cooperative working with male

${ }^{80}$ Anonymous, 'Asylum reports for 1903', JMS, 50 (1904), p. 574.

${ }^{81}$ Alexander, Eliza Jane Aikman, p. 11.

82 J.E. Caldwell, Self-assessments Skills of Occupational Therapy Students. (Unpublished thesis, Robert Gordon University, 1997). Available from OpenAIR@RGU. [online]. Available from: http://openair.rgu.ac.uk [Accessed 18 June 2016], p. 4.

${ }^{83}$ D.K. Henderson, 'Occupational Therapy. A Series of Papers read at a Meeting of the Scottish Division held at the Glasgow Royal Mental Hospital on Friday, May 2, 1924', JMS, 71 (1925), p. 63. 
officials. ${ }^{84}$ Beyond more prominent figures like Aikman, this study additionally traced how a wider network of philanthropic women formed around the scheme to support its practical organisation. The role of collective organising in BES is similarly seen in the ways that women in Bristol used their networks to consolidate and extend influence over community affairs. ${ }^{85}$ The work ethos and values underpinning the scheme is also likely to have helped facilitate its acceptance by officials. The BES, arguably, represented an example of benevolent charity that sought to 'civilise' the poor rather than galvanise communities to protest against their conditions. ${ }^{86}$ Though at a time when public attitudes to the poor were shifting, Neil Quinn suggests that engaging with 'charitable activism' could also serve to demonstrate Poor Law officials' more benevolent side. ${ }^{87}$

Assessing the actual impact of women's efforts upon the lives of the poor is limited by an absence of sources documenting the recipients' experiences. As Frank Prochaska argues in relation to workhouse visiting, philanthropists may have made life a little less bleak but schemes such as BES did little to tackle the real conditions of poverty. ${ }^{88}$ Within the asylum there is also no substantive evidence that the BES made major inroads as a form of therapy and was only offered to a small number of patients. Nevertheless, the scheme's presence here resulted in regular contact between the

\footnotetext{
${ }^{84}$ King, Women, Welfare and Local Politics, p. 121-126; Martin, 'Single Women and Philanthropy', p. 412.

${ }^{85}$ Martin, ‘Single Women and Philanthropy', p. 408.

${ }^{86} \mathrm{M}$. Pierse, 'From lace making to social activism: the resourcefulness of campaigning women philanthropists' in L.M. Geary and O. Walsh (ed), Philanthropy in Nineteenth century Ireland, (Dublin: Four Court's Press, 2015), p.206.

${ }^{87}$ Quinn, 'Men of Yesterday', p. 15-16.

${ }^{88}$ Prochaska, Women and Philanthropy, p. 181.
} 
community and the asylum through the women's visits that went beyond the role of officials or family member.

The term 'economies of makeshift' defines the strategies of survival used by the poor that included charity, kinship support or illegal means as well as parish relief. ${ }^{89}$ King and Alannah Tomkins make the point that while access to charity is generally assumed in the historiography to have decreased in light of more institutionalised responses to welfare, there are likely to be contextual variations in how this was experienced by different groups. ${ }^{90}$ This is particularly relevant to Scotland's Poor Law arrangements, given the formal exclusion of the unemployed from relief. Research by Andrew Blaikie in the north east of Scotland has found that kinship networks 'were expected to oblige' before official sources of relief were pursued, although Blaikie does not identify if charity also formed part of this 'makeshift economy'. ${ }^{91}$ In Glasgow, Johnston suggests that access to charity remained an intrinsic means of support for the unemployed poor during economic insecurity in the late $19^{\text {th }}$ century. ${ }^{92}$

There is no evidence from this case study that the BES was intended as a form of 'relief' for those within the poorhouse, although participants did 'earn' additional amenities through their involvement. The scheme's extension to asylum patients does, however, indicate that Poor Law officials and philanthropists were mindful of tensions in the welfare system for particular groups. While 'recovered' patients were no longer the responsibility of the asylum, nor where they necessarily eligible for parish relief.

\footnotetext{
${ }^{89}$ A. Tomkins and S. King (ed.), The Poor in England 1700-1850: An Economy of Makeshifts. (Manchester University Press, 2003), p. 1.

${ }^{90}$ Ibid., p.271.

${ }^{91}$ Blaikie, 'Accounting for Poverty', p. 221.

92 Johnston, 'Charity That Heals', p. 78-80.
} 
Further investigation of this association and its English counterpart is needed to understand how it functioned as a means of support for the poor. It is feasible that BACA's link to the Poor Law meant that the scheme was more oriented towards paid work rather than grounded in a philosophy of convalescence. The involvement of the Inspector of the Poor and a Brabazon committee of women administering aid may also have resulted in judgements about the cases deemed most 'deserving' of charity.

Reconstructing women's local experiences is, as King points out, a time consuming task because it involves piecing together often neglected or uncatalogued records. ${ }^{93}$ Researching the BES required investigation of various source materials to develop a profile of the scheme and to understand the roles of the women involved. A limitation was an absence of personal accounts by local women that might have offered insights into their public experiences. While the focus in one city allowed for a more in-depth study, multi-site fieldwork would enable a systematic comparison of women's experiences within different institutions and geographical settings. Linking up Poor Law records with those of local philanthropic initiatives would also offer a more detailed picture of how charity continued to be accessed by the poor and the extent, as Patricia Hollis suggests, that municipal and philanthropic activities 'developed alongside and enlarged each other' in the final decades of the Poor Law. ${ }^{94}$

\section{Acknowledgements}

The primary research upon which this article is based was partially funded with financial support of the Department of History and Faculty of Arts at University of Stirling.

\footnotetext{
93 King, Women, Welfare and Local Politics, p. 19.

${ }^{94}$ Hollis, Ladies Elect, p. 20.
} 
